\title{
Structure and amount of genetic variation at minisatellite loci within the subspecies complex of Phoca vitulina (the harbour seal)
}

\author{
A. L. KAPPE,+ R. BIJLSMA + , A. D. M. E. OSTERHAUS $\ddagger, W$. VAN DELDEN $\dagger$ \\ \& L. VAN DE ZANDE* $\dagger$ \\ tDepartment of Genetics, University of Groningen, PO Box 14, NL-9750 AA Haren and $\$$ Seal Rehabilitation and \\ Research Centre, Hoofdstraat 94, NL-9968 AG Pieterburen, The Netherlands
}

\begin{abstract}
The structure and amount of genetic variation within and between three subspecies of the harbour seal Phoca vitulina was assessed by multilocus DNA fingerprinting. Bandsharing similarity indicates that the subspecies Phoca vitulina richardsi (Alaska, East Pacific) is clearly separated from the other two subspecies, Phoca vitulina concolor (Sable Island, West Atlantic) and Phoca vitulina vitulina (North Sea, East Atlantic). The subspecies also differ significantly in the estimated amount of heterozygosity. Phoca vitulina richardsi has by far the highest amount of genetic variation, whereas $P$. vitulina vitulina has very low levels of genetic variation. Within the subspecies $P$. vitulina vitulina, especially the Wadden Sea population is depauperate of genetic variation. The findings are discussed in a historical, biogeographical and a conservation biological context.
\end{abstract}

Keywords: conservation genetics, DNA fingerprinting, genetic variation, harbour seal.

\section{Introduction}

A central topic in conservation biology is the assessment of the amount of genetic variation and the description of genetic structure in plant and animal species, especially endangered species. Genetic variation is considered to be of major importance for the adaptability of populations and species to changing and deteriorating environments (SchonewaldCox et al., 1983; Lynch \& Lande, 1993). Moreover, loss of genetic variation and an increase in homozygosity caused by genetic drift and inbreeding can result in a significant decrease in fitness (inbreeding depression) and consequently to an elevated risk of extinction (Frankel \& Soulé, 1981; Schonewald-Cox et al., 1983; Soulé, 1987; Hedrick \& Miller, 1992; Bijlsma et al., 1994). An often cited example of a species that possibly has passed through several bottlenecks and suffers from an exceptional loss of genetic variation is the southern African cheetah (O'Brien et al., 1987). In this species a low rate of reproduction and a high susceptibility to infectious agents was observed, for which both the extremely

\footnotetext{
*Correspondence. E-mail: zandelpw@biol.rug.nl
}

low level of genetic variation (O'Brien et al., 1985) and very poor environmental conditions (Caro \& Laurenson, 1994) were indicated as the main cause. Recently, studies on the Florida panther (Barone et al., 1994; Fergus, 1995; Hedrick, 1995) and the song sparrow (Keller et al., 1994) have described the combined effects of inbreeding depression and environmental challenges in natural populations.

Merola (1994) and Caughly (1994) have questioned the relative importance of genetic variation in species conservation, especially in the case of the cheetah. They argue that deterioration of natural habitats and poor conditional factors are the main cause of increased vulnerability. Moreover, low levels of genetic variation are supposed to be inherent to carnivorous terrestrial and marine mammals (Merola, 1994). Evidence that reduced genetic variability does not inevitably impair fitness has been observed for a reintroduced population of beavers (Castor fiber) in Sweden. This population shows high viability despite the very low levels of genetic variation (Ellegren et al., 1993). However, sound empirical data concerning the importance of genetic processes in nature are still lacking and more research on the genetics of endangered species is needed. 
In a previous study the genetic variation in North Sea populations of the harbour seal (Phoca vitulina vitulina) was examined and very low levels of overall genetic variation were demonstrated by DNA fingerprinting and allozyme electrophoresis (Kappe et al., 1995; Swart et al., 1996). Furthermore, this population has suffered from deteriorating habitat quality caused by human activities (de Swart, 1995). Therefore, the North Sea population of the harbour seal has experienced both environmental and genetic stresses.

For the harbour seal four subspecies have been described on the basis of morphology in taxonomic studies. These subspecies are: $P$. vitulina vitulina (East Atlantic), P. vitulina concolor (West Atlantic), $P$. vitulina richardsi (East Pacific) and $P$. vitulina stejnegeri (West Pacific). This subdivision has recently been confirmed by mitochondrial cytochrome $b$ (Arnason et al., 1995) and control region (Stanley et al., 1996) sequence data. The existence of these subspecies makes it possible to address the correlation between genetic variation on the one hand and geographical separation, climatological history, habitat quality and population size on the other. It may also give an answer to the question whether the low level of genetic variation described by Kappe et al. (1995) for the North Sea population is specific for this population only, or is a characteristic of the whole species complex. As a first step, we have determined the level of genetic variation in the subspecies $P$. vitulina vitulina, $P$. vitulina concolor and $P$. vitulina richardsi.

\section{Materials and methods}

\section{Blood samples}

Forty-six samples were collected from the Dutch Wadden Sea and 20 samples were collected from the East coast of Scotland. Both populations belong to the subspecies $P$. vitulina vitulina. Twenty-two samples were collected from a population from Sable Island, New Brunswick, Canada, belonging to the subspecies $P$. vitulina concolor. Twelve samples were collected from Prince William Sound, Alaska and 10 samples were taken at south-east Alaska. Both these latter populations belong to the subspecies $P$. vitulina richardsi.

\section{DNA extraction}

DNA was isolated from $5 \mathrm{~mL}$ whole blood collected in EDTA anticoagulant vacutainers. DNA was extracted by proteinase $\mathrm{K}$ digestion $\left(100 \mu \mathrm{g} \mathrm{mL}^{-1}\right)$ at $55^{\circ} \mathrm{C}$ overnight in lysis buffer $(10 \mathrm{~mm}$ Tris- $\mathrm{HCl}, \mathrm{pH}$ 7.4, $100 \mathrm{~mm} \mathrm{NaCl}, 25 \mathrm{~mm}$ EDTA, pH 8.0, 0.5 per cent SDS (w/v)), and purified by several extractions with phenol and chloroform:isoamyl-alcohol (24:1).

\section{DNA fingerprinting}

Five micrograms of DNA were digested to completion with 15 units restriction enzyme HinfI. DNA fragments were resolved on a 0.8 per cent agarose gel, without ethidium bromide, in TBE buffer $(0.089$ м Tris, $0.089 \mathrm{M}$ boric acid, $0.002 \mathrm{M}$ EDTA) for $60 \mathrm{~h}$ at $1.8 \mathrm{~V} \mathrm{~cm}^{-1}$. After electrophoresis the DNA fragments were transferred to nylon membranes (Hybond-N, Amersham) by vacuum-blotting and crosslinked by UV illumination.

Minisatellite probes 33.6 and 33.15 (Jeffreys et al., $1985)$ were labelled with $\alpha-{ }_{-1}^{32} \mathrm{P}$ by random-primed DNA labelling (Feinberg \& Vogelstein, 1983). Filters were prehybridized at $65^{\circ} \mathrm{C}$ in $0.263 \mathrm{M}$ $\mathrm{Na}_{2} \mathrm{HPO}_{4}$, pH 7.2, 7 per cent SDS (w/v), $1 \mathrm{~mm}$ EDTA, for $1 \mathrm{~h}$. Hybridization was carried out overnight at $65^{\circ} \mathrm{C}$ in the same buffer. Filters were washed with $2 \times \mathrm{SSC}, 0.1$ per cent SDS for $10 \mathrm{~min}$ at room temperature. The filters were exposed to Kodak X-OMAT X-ray film for $1-3$ days at $-70^{\circ} \mathrm{C}$ using intensifying screens.

\section{Data analysis}

All clear bands in the range of $6-20 \mathrm{~kb}$ were scored manually. The coefficient of band-sharing between individuals was calculated as $S_{x y}=2 n_{x y} /\left(n_{x}+n_{y}\right)$, where $n_{x}$ and $n_{y}$ are the number of bands present in individuals $x$ and $y$, respectively, and $n_{x y}$ is the number of bands shared by $x$ and $y$ (Wetton et al., 1987).

Mean population similarity was estimated by averaging the similarities of all pairs of individuals in the sample. The standard error of the mean similarity was estimated by the method of Lynch (1990), which considers variances and covariances between similarity indices. All overlapping pairs of individuals were used to estimate the sampling variance. Covariance of overlapping similarities was estimated using all possible pairwise combinations sharing one individual (Kappe et al., 1995). Differences between band-sharing coefficients were tested by a two-tailed $t$-test.

The average heterozygosity was estimated according to Stephens et al. (1992) as $H=\left[\Sigma s_{k}\right]$ $\left.\left(A-\Sigma \sqrt{ }\left(1-s_{k}\right)\right)\right]-1$, where $s_{k}$ is the frequency of the $k$ th fragment in the sample, and $A$ is the total number of fragments observed overall at polymorphic and monomorphic loci.

(C) The Genetical Society of Great Britain, Heredity, 78, 457-463. 
Based on the similarity $S$, the genetic difference $D$ is defined as 1-S (Puterka et al., 1992; van de Zande \& Bijlsma, 1995). Based on $D$, a distance tree was constructed using the program NEIGHBOR from the package PHYLIP (Felsenstein, 1993).

\section{Results}

Variable multibanded patterns with both 33.6 and 33.15 human minisatellite probes were observed in all harbour seal populations (Fig. 1). Bands were scored in the range of $6-20 \mathrm{~kb}$ in all populations. With the probes 33.6 and 33.15 totals of 62 and 91 informative bands were analysed, respectively. No specific bands that could be used diagnostically for a particular population were identified. In several cases, however, bands were observed that were predominantly present in one or two populations but were largely absent in another.

\section{Within populations and subspecies}

The results of band-sharing analysis within populations of the harbour seal are presented in Table 1. The band-sharing coefficients found, for both

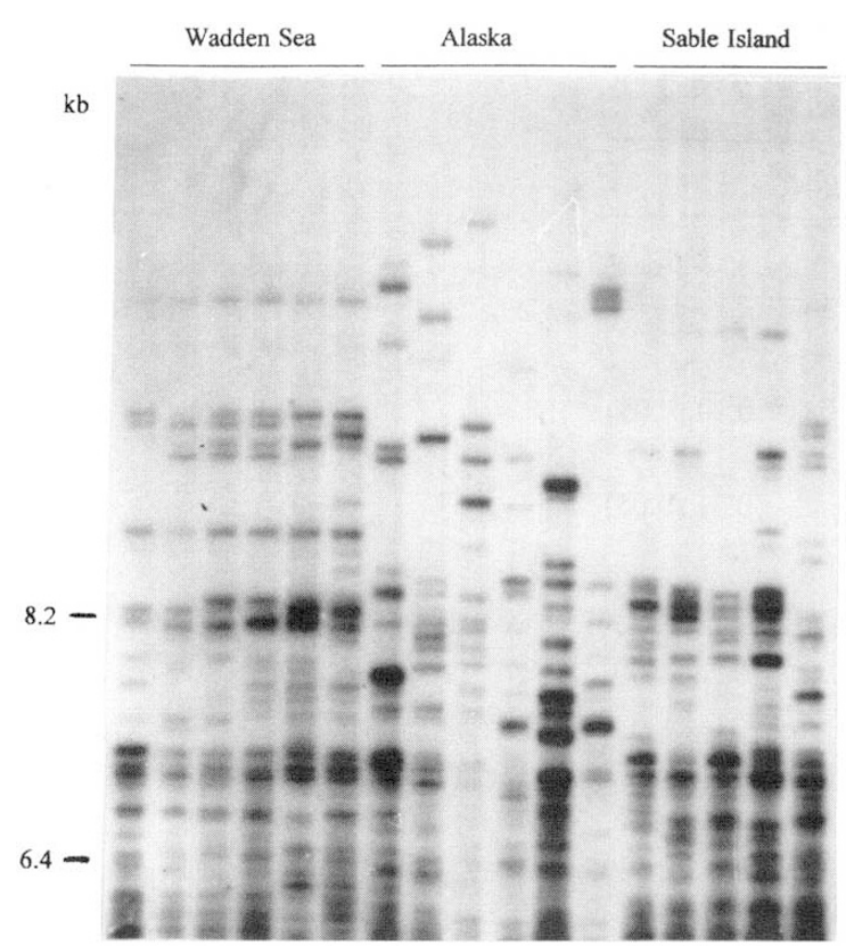

Fig. 1 DNA fingerprints of Phoca vitulina; six individuals from the Dutch Wadden Sea (lanes 1-6), six individuals from Prince William Sound, Alaska (lanes 7-12) and five individuals from Sable Island (lanes 13-17). DNA was digested with HinfI and hybridized with probe 33.15 . probes, in both the Wadden Sea population and the Scottish population were found to be very high, confirming previous results, based on smaller sample sizes (Kappe et al., 1995). Band-sharing coefficients within the Sable Island population are 0.69 and 0.62 for probes 33.6 and 33.15, respectively, and are significantly lower than the values found for the North Sea populations. In the Prince William Sound population band-sharing coefficients within the population are 0.40 and 0.33 for probes 33.6 and 33.15 , respectively. For the south-east Alaska population these values are 0.36 and 0.33 . These values are significantly lower than the values found for both the North Sea and the Sable Island population.

The estimated average heterozygosity values calculated from the fingerprint data are presented in Table 2. The subspecies from the North Sea, in

Table 1 Average band-sharing coefficients, $\overline{\mathrm{S}}$, within populations in the harbour seal detected by multilocus probes 33.6 and 33.15 . Numbers in brackets represent standard errors, $n$ indicates number of individuals

\begin{tabular}{llcc}
\hline & & \multicolumn{2}{c}{ Probe } \\
\cline { 3 - 4 } & $n$ & 33.6 & 33.15 \\
Populations & & & \\
\hline $\begin{array}{l}\text { Phoca vitulina vitulina } \\
\quad \text { Wadden Sea }\end{array}$ & 46 & $0.84(0.04)$ & $0.87(0.01)$ \\
$\quad \begin{array}{l}\text { Scotland } \\
\text { Phoca vitulina concolor }\end{array}$ & 20 & $0.83(0.01)$ & $0.79(0.01)$ \\
$\quad$ Sable Island & 22 & $0.69(0.05)$ & $0.62(0.02)$ \\
$\begin{array}{l}\text { Phoca vitulina richardsi } \\
\quad \text { Prince William Sound }\end{array}$ & 12 & $0.40(0.02)$ & $0.33(0.03)$ \\
$\quad$ South-east Alaska & 10 & $0.36(0.01)$ & $0.33(0.02)$ \\
\hline
\end{tabular}

Table 2 Estimated average heterozygosity within populations in the harbour seal detected by multilocus probes 33.6 and 33.15. $n$ indicates number of individuals

\begin{tabular}{llll}
\hline & & \multicolumn{2}{c}{ Probe } \\
\cline { 4 - 4 } & $n$ & 33.6 & 33.15 \\
Populations & & & \\
$\begin{array}{l}\text { Phoca vitulina vitulina } \\
\quad \text { Wadden Sea }\end{array}$ & 46 & 0.19 & 0.18 \\
$\quad$ Scotland & 20 & 0.37 & 0.28 \\
$\begin{array}{l}\text { Phoca vitulina concolor } \\
\quad \text { Sable Island }\end{array}$ & 22 & 0.38 & 0.45 \\
$\begin{array}{l}\text { Phoca vitulina richardsi } \\
\quad \text { Prince William Sound } \\
\quad \text { South-east Alaska }\end{array}$ & 12 & 0.60 & 0.65 \\
\hline & 10 & 0.68 & 0.67 \\
\hline
\end{tabular}


particular the Wadden Sea population, show very low estimated average heterozygosities, which is in agreement with previous results (Kappe et al., 1995). The populations from Sable Island and Alaska show increasingly higher values. The populations from Alaska have by far the highest level of heterozygosity compared to all other populations.

\section{Between subspecies}

For the calculation of mean band-sharing coefficients between subspecies, both North Sea populations and both Alaska populations were clustered. The mean band-sharing coefficients between subspecies (Table 3) are significantly lower compared to the values found within populations (Table 1). For both $P$. vitulina vitulina and $P$. vitulina richardsi the band-sharing values for interpopulation comparison were higher than for comparison at the subspecies level (Tables 1 and 3). For probe 33.6 all comparisons between subspecies differ significantly from each other. Data from probe 33.15 discriminate only between the subspecies $P$. vitulina richardsi and $P$. vitulina vitulina. Nevertheless, for both probes the same trend is observed: a higher band-sharing coefficient between subspecies from the North Atlantic than between the subspecies from the North Pacific and from the North Atlantic. Using the genetic difference $(D)$ for probe 33.6 , a distance tree containing all five populations was constructed (Fig. 2). This tree is topologically identical to those obtained by mitochondrial sequence data (Arnason et al., 1995; Stanley et al., 1996).

\section{Discussion}

Two main conclusions can be drawn from the results. First, the three subspecies show considerable genetic divergence, reflected in the values of the bandsharing similarities (Table 3). Relatively, the similarity between subspecies is significantly smaller than between populations within subspecies. This may indicate that gene flow between subspecies is limited. The similarity tree that can be constructed based on our multilocus fingerprint data is topologically identical to that reported based on mitochondrial cytochrome $b$ sequences, placing the subspecies $P$. vitulina richardsi clearly separated from the other two subspecies. Although no fingerprint bands were observed that occurred in one subspecies
Table 3 Comparison of band-sharing coefficients, $\overline{\mathrm{S}}$, between harbour seal populations and subspecies, by multilocus probes 33.6 and 33.15. Numbers in brackets represent standard errors

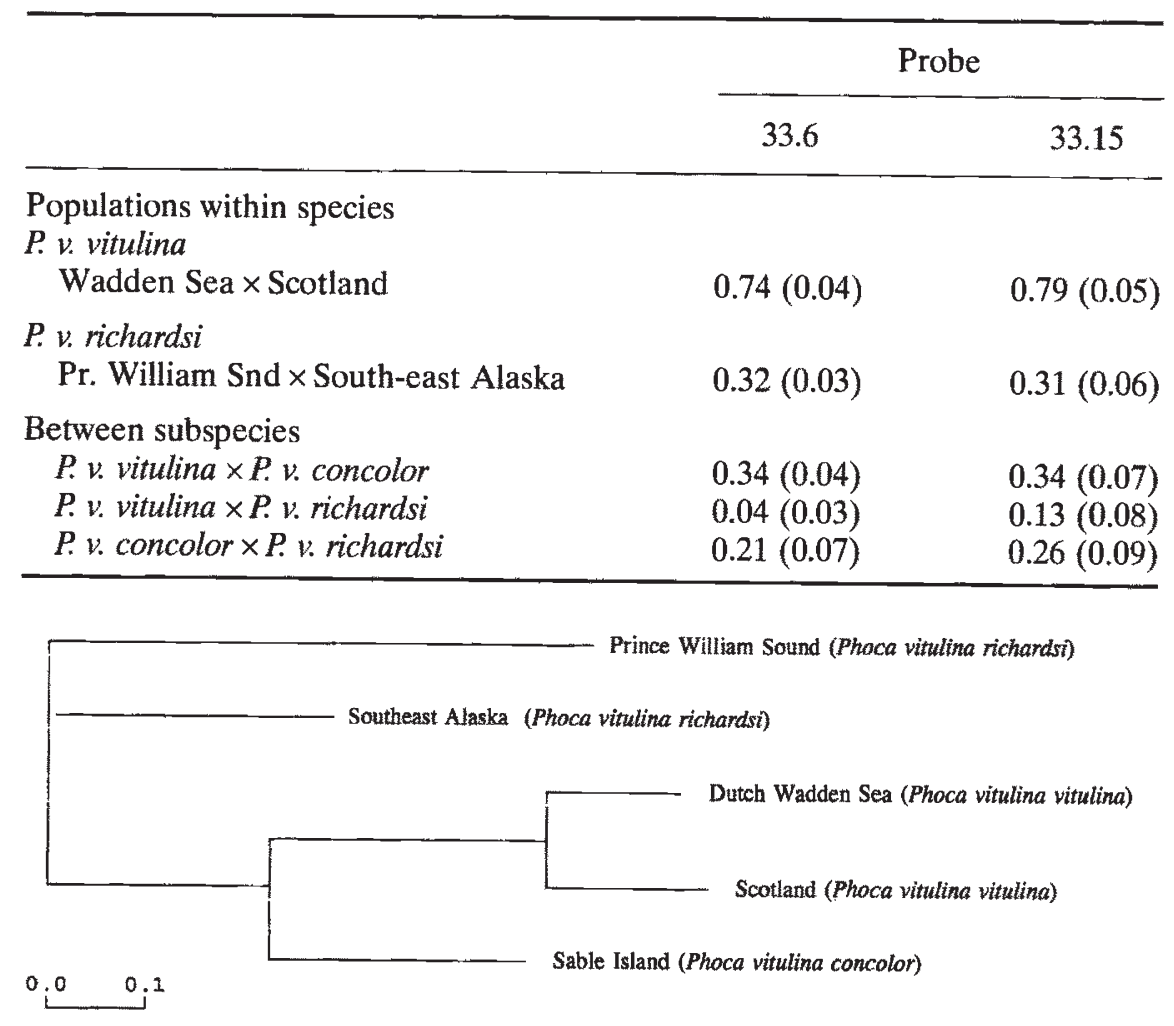

Fig. 2 Neighbour-joining tree based on band-sharing coefficients between populations of Phoca vitulina; bar indicates genetic difference of 0.1 . 
only, the subspecies $P$. vitulina richardsi has more bands which are predominantly associated to this subspecies. Apparently, the barrier posed by the pack ice in the high Arctic is a substantial geographical barrier (Stanley et al., 1996). Some gene flow may exist between the West and East Atlantic subspecies, although both subspecies show significant divergence.

The second conclusion is that there is a highly significant difference in the level of genetic variation within the three subspecies. In accordance with the difference in band-sharing similarities, reflecting the overall genetic variation, the estimated heterozygosity also differs considerably between the three subspecies. The highest level of heterozygosity is observed in the subspecies $P$. vitulina richardsi. Significantly lower levels of heterozygosity are observed in $P$. vitulina concolor and the lowest level in $P$. vitulina vitulina.

Compared to the subspecies dwelling in the East Atlantic and West Pacific waters, the harbour seal subspecies in the North Sea has an extremely low level of overall genetic variation. As reported before, the grey seal (Halichoerus grypus), a marine carnivore living in the same habitat, has significantly higher levels of genetic variation (Kappe et al., 1995). This indicates that the low levels of genetic variation found in the North Sea harbour seal are not the consequence of being a carnivorous marine mammal per se. Moreover, data based on mitochondrial cytochrome $b$ sequences have indicated that the grey seal should be included in the genus Phoca (Arnason et al., 1995). This implies that the observed low level of overall genetic variation of $P$. vitulina vitulina is not a characteristic of the genus Phoca, nor of the species $P$. vitulina because an appreciable amount of genetic variation is present in at least two subspecies. Therefore, our results indicate that especially the subspecies $P$. vitulina vitulina is depauperate of genetic variation. Within this subspecies, the population from the Wadden Sea has by far the lowest level of heterozygosity.

The structure and distribution of genetic variation is strongly influenced by historical events and demographic history of populations, associated with population fragmentation, bottlenecks and range expansion. Undoubtedly the last Northern Hemisphere glaciation has caused a dramatic reduction of population size for most large mammal species (Marshall et al., 1982; Menotti-Raymond \& O'Brien, 1993). Both the West Atlantic and East Pacific regions were less covered with ice during the last glaciation (Peltier, 1994). Therefore, both the subspecies $P$. vitulina richardsi and $P$. vitulina conco- lor probably did experience a significantly less severe bottleneck during the last glaciation than the subspecies $P$. vitulina vitulina. This might explain why the North Sea has become depauperate of genetic variation compared to the other regions. If we assume that during this bottleneck almost all minisatellite variation in $P$. vitulina vitulina was lost, using the same reasoning as was used by MenottiRaymond \& O'Brien (1993), we can estimate the date of the bottleneck. When modal generation time is assumed to be 6 years and a mutation rate between $10^{-3}$ and $5 \times 10^{-4}$ is accepted, the present level of genetic variation in the subspecies $P$. vitulina vitulina does not contradict the assumption of a bottleneck some 10000 years ago.

There is a striking correlation between low levels of genetic variation and susceptibility to the Phocine Distemper Virus (PDV). In the North Sea 40-60 per cent of the individuals were killed by the virus, the Wadden Sea being the area with the highest mortality (Reijnders \& Lankester, 1990). In Alaska, no mortality caused by PDV has been reported for P. vitulina richardsi, although seropositive animals have been recorded (L. Lowry, personal communication; Frost et al., 1994) indicating that the virus is present in this subspecies. For $P$. vitulina concolor there were low levels of mortality caused by PDV and some seropositive animals were observed in 1992 (National Marine Fisheries Service, 1993).

The reasons for this difference in susceptibility to PDV could be: (i) the virus was new to the North Sea subspecies but enzootic in the West Atlantic and East Pacific subspecies, giving them higher resistance because of existing immunity; (ii) pollution levels, especially with polyhalogenated aromatic hydrocarbons, are higher in the North Sea region than in the Canadian and Alaskan waters (these compounds can seriously affect the immune response; Ross, 1995; de Swart, 1995); (iii) P. vitulina vitulina is not able to react adequately to the viral infection because of its low level of genetic variation. Our results can neither exclude nor sustain any of these reasons in particular. However, given the fact that within the North Sea region particularly the Wadden Sea population suffered the highest mortality, it is suggestive that low levels of heterozygosity are at least partly responsible for the high susceptibility of this population for PDV.

\section{Acknowledgements}

We would like to thank the following people who kindly provided samples used in this study: the Dutch Seal Rehabilitation and Research Centre, 
Pieterburen, the Netherlands; W. D. Bowen, Bedford Institute of Oceanography, Dartmouth, Nova Scotia, Canada; and L. F. Lowry, Department of Fish and Game, Fairbanks, Alaska, USA. We thank $\mathrm{H}$. Mulder for preparing the illustrations.

\section{References}

ARNASON, U., BODIN, K., GULlBERG, A., LEDJE, C. AND MOUCHATY, s. 1995. A molecular view of pinniped relationships with particular emphasis on the true seals $J$. Mol. Evol., 40, 78-85.

BARONE, M. A., ROELKE, M. E., HOWARD, J., BROWN, J. L., ANDERSON, A. E. AND WILDT, D. E 1994. Reproductive characteristics of male florida panthers: comparative studies from Florida, Texas, Colorado, Latin America, and American zoos. J. Mammal., 75, 150-162.

BIJLSMA, R., OUBORG, N. J. AND VAN TREUREN, R. 1994. On genetic erosion and population extinction in plants: a case study in Scabiosa columbaria and Salvia pratensis. In: Loeschcke, V., Tomiuk, J. and Jain, S (eds) Conservation Biology, pp. 255-271. Birkhauser Verlag, Basel, Switzerland.

CARO, T. M. AND LAURENSON, K. M. 1994. Ecological and genetic factors in conservation: a cautionary tale. Science, 236, 485-487.

CAUGHLY, G. 1994. Directions in conservation biology. $J$. Anim. Ecol., 63, 215-244.

DE SWART, R. L. 1995. Impaired Immunity in Seals Exposed to Bioaccumulated Environmental Contaminants. $\mathrm{PhD}$ Thesis, Erasmus University, Rotterdam, The Netherlands.

ELlEGREN, H., HARTMAN, G., JOHANSSON, M. AND ANDERSSON, L. 1993. Major histocomatibility complex monomorphism and low levels of DNA fingerprinting variability in a reintroduced and rapidly expanding population of beavers. Proc. Natl. Acad. Sci. U.S.A., 90, 8150-8153.

FEINBERG, A. P. AND VOGELSTEIN, B. 1983. A technique for radiolabelling DNA restriction endonuclease fragments to high specific activity. Analyt. Biochem., 132, 6-13.

FELSENSTEIN, J. 1993. PHYLIP (Phylogeny Inference Package) Version 3.5p. March 1993. Department of Genetics, University of Washington, Seattle.

FERGUS, C. 1995. The florida panther verges on extinction. Science, 251, 1178-1180.

FRANKEL, O. H. AND SOUlé, M. E 1981. Conservation and Evolution. Cambridge University Press, Cambridge.

FROST, K. J., LOWRY, L. F., SINCLAIR, E. H., VER HOEF, J. AND MCALlister, D. C. 1994. Impacts on distribution, abundance, and productivity of harbor seals. In: Loughlin, T.R (ed.) Marine Mammals and the Exxon Valdez, pp. 97-118. Academic Press, San Diego, CA.

HEDRICK, P. W. 1995. Gene flow and genetic restoration: the Florida panther as a case study. Conserv. Genet., 9, 996-1007.

HEDRICK, P. W. AND MILlER, P. S. 1992. Conservation genetics: techniques and fundamentals. Ecol. Appl., 2 , 30-46.

JEFFREYS, A. J., WILSON, V. AND THEIN, S. L. 1985. Hypervariable 'minisatellite' regions in human DNA. Nature, 314, 67-73.

KAPPE, A. L., VAN DE ZANDE, L., VEDDER, E. J., BIJLSMA, R, AND VAN DELDEN, w. 1995. Genetic variation in Phoca vitulina (the harbour seal) revealed by DNA fingerprinting and RAPDs. Heredity, 74, 647-653.

KELlER, L. F., ARCESE, P., SMITH, J. N. M., HOCHACHKA, W. M. AND STEARNS, S. C. 1994. Selection against inbred song sparrows during a natural population bottleneck. Nature, 372, 356-357.

LYNCH, M. 1990. The similarity index and DNA fingerprinting. Mol. Biol. Evol., 7, 478-484.

LYNCH, M. AND LANDE, R. 1993. Evolution and extinction in response to environmental change. In: Kareiva, P.M., Kingsolver, J.G. and Huey R.B (eds) Biotic Interactions and Global Change, pp. 234-250. Sinauer, Sunderland, MA.

MARSHALL, L. G., WEBB, S. D., SEPKOSK1, J. J., JR AND RAUP, D. M. 1982. Mammalian evolution and the great American interchange. Science, 215, 1351-1357.

MENOTT1-RA YMOND, M. AND O'BRIEN, s. J. 1993. Dating the genetic bottleneck of the African cheetah. Proc. Natl. Acad. Sci. U.S.A., 90, 3172-3176.

MEROLA, M. 1994. A reassessment of homozygosity and the case for inbreeding depression in the Cheetah, Acinonyx jubatus: implications for conservation. Conserv. Biol., 8, 961-971.

NATIONAL MARINE FISHERIES SERVICE 1993. Our Living Oceans. Annual report of the National Marine Fisheries Service, unit 22.

O'BRIEN, S. J., ROELKE, M. E., MARKER, L., NEWMAN, A., WINKLER, C. A., MELTZER, D. ET AL. 1985. Genetic basis for species vulnerability in the cheetah. Science, 227, 1428-1434.

O'BRIEN, S. J., WILDT, D. E., BUSH, M., CARO, T. M., FITZGIBBON, C., AGGYNDEY, I. AND LEAKEY, R. E. 1987. East African cheetahs: evidence for two population bottlenecks? Proc. Natl. Acad. Sci. U.S.A., 84, 508-511.

PELTIER, W. R. 1994. Ice Age paleotopography. Science, 265, 195-201.

PUTERKA, G. J., BLACK W. C. IV, STEINER, W. M. AND BURTON, R. L. 1992. Genetic variation and phylogenetic relationships among worldwide collections of the Russian wheat aphid, Diuraphis noxia (Mordvilko) inferred from allozyme and RAPD-PCR markers. Heredity, 70, 604-618.

REINDERS, P. J. H. AND LANKESTER, K. 1990. Status of marine mammals in the North Sea. Neth. J. Sea Res. 26, 427-435.

Ross, P. S. 1995. Seals, Pollution and Disease: Environmental Contaminant-Induced Immunosuppression. PhD Thesis, University of Utrecht, The Netherlands.

SCHONEWALD-COX, C. S., CHAMBERS, S. M., MACBRYDE, B. AND THOMAs, L. 1983. Genetics and Conservation: $a$ Reference for Managing Wild Animal and Plant Populations. Benjamin-Cummings, London. 
SOUlÉ, M. E. 1987. Viable Populations for Conservation. Cambridge University Press, Cambridge.

STANLEY, H. F., CASEY, S., CARNAHAN, J. M., GOODMAN, S., HARWOOD, J. AND WAYNE, R. K. 1996. Worldwide patterns of mitochondrial DNA differentiation in the Harbor Seal (Phoca vitulina). Mol. Biol. Evol., 13, 368-382.

STEPHENS, J. C., GILBERT, D. A., YUHKI, N. AND O'BRIEN, S. J. 1992. Estimation of heterozygosity for single-probe multilocus DNA fingerprints. Mol. Biol. Evol., 9, 729-743.
SWART, J. A. A., REIJNDERS, P. J. H. AND VAN DELDEN, W. 1996. Absence of genetic variation in Harbor Seals (Phoca vitulina) in the Dutch Wadden Sea and the British Wash. Conserv. Biol., 10, 1-6.

VAN DE ZANDE, L. AND BULLSMA, R. 1995. Limitations of the RAPD technique in phylogeny reconstruction in Drosophila. J. Evol. Biol., 8, 645-656.

WETTON, J. H., CARTER, R. E., PARKIN, D. T. AND WALTERS, D. 1987. Demographic study of a wild house sparrow population by DNA 'fingerprinting'. Nature, 327, 147-149. 